\title{
Relationship between Agglutinative Properties of Aeromonas salmonicida Strains Isolated from Fish in Japan and Their Resistance to Mechanisms of Host Defense
}

\author{
Daiku K. SAKaI ${ }^{* 1}$ and Takahisa KIMURA*2 \\ ${ }^{* 1}$ Hokkaido Fish Hatchery, Nakanoshima 2, Toyohira, Sapporo 062, Japan \\ ${ }^{* 2}$ Faculty of Fisheries, Hokkaido University, Minato-cho, Hakodate 041, Japan
}

(Received October 6, 1984)

\begin{abstract}
Phenotypic variation in spontaneous agglutination of Aeromonas salmonicida was investigated using 114 strains isolated from naturally epizootics of furunculosis in salmonid fish in Japan from 1967 through 1982. These strains were categorized into three different types: an agglutinating (AG) type which produced cell flocks resulting in precipitation and loss of turbidity in cell suspensions; a nonagglutinating (NAG) type, representing no loss in turbidity; and an intermediate (IM), weakly autoagglutinating type. Based on the occurrence of the AG, NAG and IM types determined in 1978 and again 1982, it was shown that a transition occurs progressing from the AG to the NAG via the IM type. The strains involved in the AG and NAG types were virulent and avirulent, respectively, based on $\mathrm{LD}_{50}$ determination in rainbow trout (Salmo gairdneri). The NAG type was much less susceptible than the AG to the bactericidal activity of fresh normal rainbow trout serum, to immune bacteriolysis and to phagocytosis by cells from pertioneal exudate. When growth properties of AG and NAG types were compared under mixed culture conditions, the NAG type predominated in the culture broth 2-5 days after inoculation. In contrast, when rainbow trout were inoculated intraperitoneally with cells of both types, the NAG-type cells were selectively eliminated from the kidneys within a period of a few days. The AG-type cells, however, greatly proliferated in the kidneys and brought about clinical furunculosis. These results indicate that the AG type possesses a capacity to escape the defense mechanisms of the host by resisting the bactericidal activity of serum and phagocytosis by leucocytes.
\end{abstract}

\section{Introduction}

Aeromonas salmonicida, the causative agent of furunculosis is an important pathogen of fish from the fry to the adult stage (HeRman, 1968; KLONTZ et al., 1966; MCCARTHY and ROBERTs 1980). Isolates from naturally occurring furunculosis in salmonids occur in two different forms, those showing spontaneous agglutination (autoagglutination) and those that fail to do so (EvENBERG et al., 1982; IsHIGURo et al., 1981; KAY et al., 1981). The property of agglutination is considered important to the pathogenicity of $A$. salmonicida strains. UDEY and FRYER (1978) reported that the cells of virulent strains are autoagglutinative and possess an additional outer layer (A layer). This A layer is in addition to the normal characteristic of Gram-negative bacteria. In contrast, nonagglutinating strains lack this layer and are avirulent. A similar correlation was also demonstrated by ISHIGURo et al. (1981) and KAY et al. (1981). A similar extra surface layer has been found in an atypical, virulent $A$. salmonicida strains from goldfish by HAMILTON et al. (1981).

The structure of the A layer in the cell envelopes represents a repeating tetragonal subunit pattern (KAY et al., 1981). The A layer protein has been isolated and characterized as 49 and 54 kilodaltons by KAY et al. (1981) and EVENBERG and LUGTENBERG (1982), respectively. They also showed similarity between the amino acid compositions of adhesive fimbriae of enteropathogenic Escherichia coli and the microcapusule of Campy. lobacter fetus. A possible role of the A layer producing adhesion to the surface of the host tissues is suggested (UDEY and FRYER, 1978). The immunogenicity of the A layer in the ag- 
glutinating strains has been demonstrated by HAHNEl et al. (1983).

This extra surface layer may be common to agglutinating or virulent strains for a wide range of diseased fish species. However, the interrelationships between the A layer, agglutination, adhesion and virulence have not been demonstrated. More work is necessary to define these differences between the agglutinating and nonagglutinating types, in order to understand why the agglutinating type is resistant to the defense mechanisms of the host fish. In this study, the tendency toward phenotypic variation in agglutination is investigated using 114 strains of $A$. salmonicida subsp. salmonicida. In addition, the different degrees of susceptibility to the bactericidal action of normal serum, immune bacteriolysis and phagocytosis by leucocytes are tested both bacterial strains using rainbow trout.

\section{Materials and Methods}

Bacterial strains and preservation: Aeromonas salmonicida subsp. salmonicida strains were used. These had been isolated from natural outbreaks of furunculosis in salmonids from 1967 through 1982 in Japan: amago salmon (Oncorhynchus rhodurus), chum salmon (Oncorhynchus keta), sockeye salmon (Oncorhynchus nerka), masu salmon (Oncorhynchus masou), pink salmon (Oncorhynchus gorbuscha), brook trout (Salvelinus fontinalis), Japanese char (Salvelinus leucomaenis), and rainbow trout (Salmo gairdneri). These isolates, 114 strains, were subcultured and preserved on nutrient agar slants (Eiken Chemical Co., Tokyo) at $15^{\circ} \mathrm{C}$, and transferred at six month intervals. In addition, strains ATCC 14174 and NCMB 1102 were maintained and used as reference strains (Table 3).

Culture and cell suspensions: All the strains were cultured on agar slants at $20^{\circ} \mathrm{C}$ for 3 days. Fresh cultures were suspended in sterile physiological saline $(0.85 \% \mathrm{NaCl})$ and the cell density was adjusted to 0.9 at optical density (OD) 610 nm. Cell suspensions were also prepared by tenfold serial dilution with saline and used as inocula. Viable cell counts were made on nutrient agar plates incubated at $20^{\circ} \mathrm{C}$ for 3 days to determine colony forming units (CFU).

Quantitative assay for spontaneous agglutina- tion: Small portions ( $2 \mathrm{ml}$ each) of cell suspensions (dispersed cell turbidity was 0.9 at OD 610 $\mathrm{nm}$ ) were used to determine the capacity for autoagglutination. Each suspension was measured in a spectrophotometer (Hitachi Model 124, Tokyo) equipped with a recorder. After the cell suspension was dispersed with a pipette, the change in turbidity was monitored by the recorder for $100 \mathrm{~min}$ at room temperature.

$L D_{50}$ determination: Juvenile rainbow trout weighing $30-40 \mathrm{~g}$ each were used for $L D_{50}$ determination. These fish were acclimatized for several weeks in laboratory aquaria supplied with fish pathogen free well water at $10^{\circ} \mathrm{C}$ and fed a commercial dry pellet daily. Five groups consisting of five fish each were injected inpraperitoneally (ip) with $0.1 \mathrm{~m} l$ of viable $A$. salmonicida cell suspensions which had been prepared by tenfold serial dilution with sterile saline. Injected fish were held for 2 weeks and mortalities recorded each day.

Acid production from sucrose: Hugh-Leifson medium (peptone $2 \mathrm{~g}, \mathrm{~K}_{2} \mathrm{HPO}_{4} 0.3 \mathrm{~g}$, agar $3 \mathrm{~g}$, and a trace of bromthymol blue dissolved in 1 liter of distilled water, $\mathrm{pH} 7.2$ ) was autoclaved at $121^{\circ} \mathrm{C}$ for $20 \mathrm{~min}$. Filtered sucrose solution was added to the medium at $1 \%(\mathrm{wt} / \mathrm{vol})$. Subcultures were stabbed in tubes containing $10 \mathrm{~m} l$ of the medium and cultured at $20^{\circ} \mathrm{C}$ for 5 days. Changes in colour were noted. Acid production (yellow) and non-production (greenish blue) were designated suc $^{+}$and suc ${ }^{-}$, respectively.

Yeast agglutination: Suspensions of glutaraldehyde-fixed yeast cells of Saccharomyces cerevisiae (commercial baker's yeast) were prepared by the method of EshDAT et al. (1978). Agglutination of yeast cells by cells of $A$. salmonicida strains was determind in the absence and presence of $\mathrm{D}$ mannose $(5-10 \%$ in final concentrations of the cell suspensions) by the method of ATKINSON and TRUST (1980).

Mixed culture: Four strains (A-7301, E-76093, NCMB 1102 and GN-7512) were used. Equal volume $(1 \mathrm{~m} l$ each) of viable cell suspensions at $10^{8-9} \mathrm{~m} l^{-1}$ were inoculated into $200 \mathrm{~m} l$ of sterile nutrient broth ( $\mathrm{pH} 7.4$ ) in 500-m $l$ Ehrlenmeyer flasks and incubated at $20^{\circ} \mathrm{C}$ with occasional shakes. After 2 and 5 days, viable cells were enumerated by colony counts. Thirty colonies from cultured nutrient agar plates were chosen at 
random and their agglutinative properties and acid production from sucrose determined. Each strain was also prepared in pure culture.

Experimental infection and reisolation: Four strains (A-7301, E-7609-3, NCMB 1102 and GN7512) were used. Rainbow trout (average wt 60 $80 \mathrm{~g}$ ) received $0.1 \mathrm{~m} l$ ip of bacterial inocula which contained $10^{8}$ viable cells $\mathrm{m} l^{-1}$ in saline. The fish were returned to laboratory aquaria and held at $10^{\circ} \mathrm{C}$. After 2 and 5 days, the kidneys were removed from dissected fish and weighed. Each kidney sample, pooled from three fish, was homogenized in two-fold saline. Viable cell counts were obtained from homogenates and the number of cells $\mathrm{g}^{-1}$ kidney calculated. Thirty colonies were then selected on the basis of agglutination and acid production from sucrose determined.

Serum collection: After anaesthetization in $m$ aminobenzoic acid ethylester methanesulphonate solution (Sankyo Co., Tokyo) at $100 \mu \mathrm{g} \mathrm{m} l^{-1}$, the blood of the rainbow trout was collected from the caudal vessel. Blood samples were pooled from three or four fish and allowed to stand at room temperature for several min. Clots were removed by centrifuging at $1000 \mathrm{~g}$ for $5 \mathrm{~min}$ at $4^{\circ} \mathrm{C}$ and the serum temporarily stored at $5^{\circ} \mathrm{C}$ until use. Complement from rainbow trout serum was heatinactivated at $44^{\circ} \mathrm{C}$ for $20 \mathrm{~min}$ (SAKAI 1981a).

Haemolytic activity of serum: Spontaneous (antibody-independent) haemolytic activity $\left(\mathrm{SH}_{50}\right)$ of normal rainbow trout serum was assayed at $30^{\circ} \mathrm{C}$ for 60 min with unsensitized red blood cells of goldfish (Carassius auratus). Details of the method and units used have been previously reported (SAKAI 1981b). Unless otherwise indicated, $\mathrm{GVB}^{2+}$ (isotonic veronal-buffered saline, $\mathrm{pH} 7.5$, containing $0.1 \%$ gelatin, $0.15 \mathrm{mM} \mathrm{CaCl}_{2}$, and $0.5 \mathrm{mM} \mathrm{MgCl}_{2}$ ) was used as a diluent for the haemolytic assay.

Bactericidal action of serum: Mixtures of equal volume $(0.5 \mathrm{~m} l$ each $)$ of fresh or heat-inac ivated serum and viable cell suspensions of four strains (A-7301, E-7609-3, NCMB 1102 and GN-7512) at $10^{4-6}$ cell $\mathrm{m} l^{-1}$ were incubated in tubes at $20^{\circ} \mathrm{C}$ for $2 \mathrm{~h}$, and shaken occasionally. As a control, sterile physiological saline $(0.5 \mathrm{~m} l)$ was applied in place of serum. The antiserums (anti-A-7301 and anti-NCMB 1102 serum) were obtained from two groups of rainbow trout $(70-120 \mathrm{~g})$, consisting of three fish each, which received ip $5 \mathrm{mg}$ of formalin-killed cells of strains A-7301 and
NCMB 1102. After 3 weeks, agglutinin titers of pooled antiserums were determined as 128 for anti-A-7301 serum and 256 for anti-NCMB 1102 serum against cells of NCMB 1102. Following incubation for the assay of bactericidal activity, the number of colonies was counted on nutrient agar plates and the viable cells $\mathrm{m}^{-1}$ calculated (CFU).

Peritoneal exudate cells (PEC): Sterilized liquid paraffin $(0.2-0.3 \mathrm{~m} l /$ fish) was injected ip into normal rainbow trout $(70-120 \mathrm{~g})$ which were maintained in aquaria at $10^{\circ} \mathrm{C}$ and sacrificial three days after the injections. The fish were bled by caudal peduncle amputation. The body surface of each was disinfected with $70 \%$ ethyl alcohol. The abdomen was dissected and the peritoneal cavity carefully washed with filtered Eagle's minimum essential medium (MEM; Gibco, New York) supplemented with $10 \%$ foetal bovine serum (Gibco) inactivated by heating at $56^{\circ} \mathrm{C}$ for $30 \mathrm{~min}$. (MEM was buffered at pH 7.2 with $10 \mathrm{~mm} \mathrm{~N}-2-$ hydroxyethylpiperazine- $\mathrm{N}^{\prime}$-ethanesulphonic acid [Sigma Chemical Co., Saint Louis, Mo.]-NaOH before filtration). Washings containing MEM and liquid paraffin were collected in silicon-coated tubes and allowed to settle at $20^{\circ} \mathrm{C}$ for $1 \mathrm{~h}$. The upper layer of liquid paraffin was discarded, and the lower layer of MEM containing the PEC was separated and washed once with MEM by centrifuging at $1000 \mathrm{~g}$ for $5 \mathrm{~min}$ at $4^{\circ} \mathrm{C}$. The live cell density of each PEC sample pooled from two or three fish was adjusted to $10^{7} \mathrm{~m} l^{-1}$ by the trypan blue exclusion test (SAKAI 1981c).

Phagocytic index of PEC: The phagocytic activity of PEC against viable cells of four $A$. salmonicida strains (A-7301, E-7609-3, NCMB 1102 and GN-7512) was determined. Each viable cell suspension $\left(0.5 \mathrm{~m} l\right.$ containing $10^{8}$ bacterial cells in MEM) was added to a mixture composed of $0.5 \mathrm{~m} l$ of PEC, $0.5 \mathrm{~m} l$ of normal rainbow trout serum as a complement source, and $0.5 \mathrm{~m} l$ of the anti-A-7301 serum in which the agglutinin titer was 256 (against NCMB 1102). Tubes containing the mixture were incubated at $20^{\circ} \mathrm{C}$ for $2 \mathrm{~h}$, with shaking to cause contact between the live bacterial cells and the PEC. Phagocytic activity was determined by applying Wright-Giemsa staining to smears of each mixture, and the numbers of phagocytosed bacteria evaluated by enumerating 500 PEC per sample under an oil-immersion 


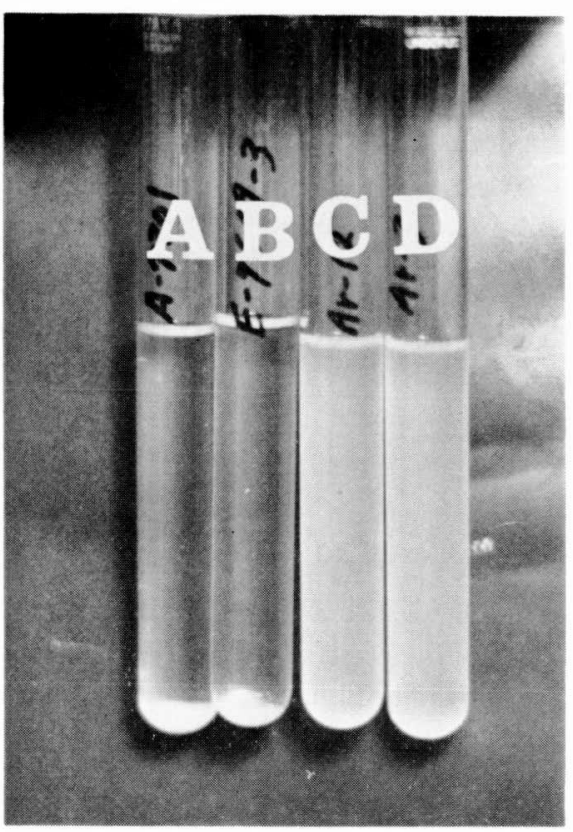

Fig. 1. Profiles of spontaneous agglutination of $A$. salmonida strains. Cells of strains A-7301 (A) and E-6709-3 (B) precipitate to the bottoms of the tubes, while cells of strains NCMB 1102 (C) and ATCC 14174 (D) show no precipitation.

microscopy $(\times 1000)$. The phagocytic index was calculated as follows:

Phagocytic index

Number of intracellular bacteria phagocytosed by PEC

Number of PEC

\section{Results}

Differences in spontaneous agglutination: When cells of $A$. salmonicida strains were suspended in saline, some strains formed visibly fine bacterial cell flocks and precipitated to the bottoms of the tubes in a short time ( 1 or $2 \mathrm{~h}$ ) (A and B in Fig. 1). No precipitation was observed in certain strains (C and D in Fig. 1). A similar difference in precipitation was found in other strains tested. Since cell flocks were easily destroyed with slight shaking, precipitation resulting from agglutination was more variable.

Differences in agglutination were determined by a quantitative turbidimetric method using cell

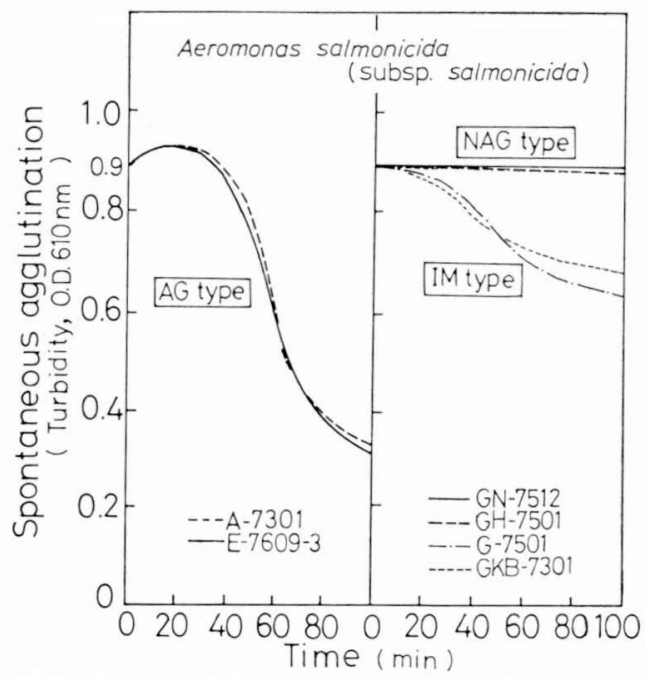

Fig. 2. Differences in agglutinative properties of $A$. salmonicida strains. Experimental method is detailed in the text.

suspensions of all the strains used. The bacterial strains were categorized into the following three types: AG type, strongly autoagglutinating cells in which changes in turbidity at OD $610 \mathrm{~nm}$ followed a reverse sigmoid curve with time; NAG type, a non-agglutinating type, representing no change in turbidity; and IM type, or intermediate cell type, showing a slight loss in turbidity of the suspensions (Fig. 2). Each type reflected differences in the capacity to produce cell flocks. The NAG type had no capacity for agglutination (strains GN-7512 and GH-7501 in Fig. 2, and strain NCMB 1102 shown in Fig. 3). The capacity of the IM type was less than that of the AG type (strain G-7501 and GKB-7301 in Fig. 2). The IM type could be determined by this turbidimetric method but could not be detected by other methods (e.g. precipitation in tubes and cell flock formation on glass slides).

Occurrence of $A G, N A G$ types: The occurrence of the AG, IM and NAG types was determined in 1978 using 75 strains isolated prior to that year (Table 1). All the strains isolated from 1967 through 1972 (6-11 years after isolation) were of the NAG type, while those from 1976 through 1978 (0-2 years) were AG. Strains from 1973 through 1975 (3-5 years) included AG, IM and NAG types. The rate of occurrence of the NAG 
Table 1. Occurrence of the AG, IM and NAG types in A. salmonicida strains isolated from naturally occurring furnuculosis in salmonids from 1967 through 1982

\begin{tabular}{|c|c|c|c|c|}
\hline \multirow{2}{*}{$\begin{array}{l}\text { Year of } \\
\text { isolation }\end{array}$} & \multicolumn{3}{|c|}{ Spontaneous agglutination of isolates } & \multirow{2}{*}{$\frac{A G}{A G+I M+N A G}(\%)$} \\
\hline & AG type & IM type & NAG type & \\
\hline \multicolumn{5}{|c|}{ Occurrence determined in 1978} \\
\hline 1967 & 0 & 0 & 1 & 0 \\
\hline 1969 & 0 & 0 & 1 & 0 \\
\hline 1970 & 0 & 0 & 2 & 0 \\
\hline 1971 & 0 & 0 & 4 & 0 \\
\hline 1972 & 0 & 0 & 10 & 0 \\
\hline 1973 & 2 & 1 & 11 & 14.3 \\
\hline 1974 & 3 & 1 & 8 & 25.0 \\
\hline 1975 & 1 & 1 & 12 & 7.1 \\
\hline 1976 & 7 & 0 & 0 & 100 \\
\hline 1977 & 3 & 0 & 0 & 100 \\
\hline 1978 & 7 & 0 & 0 & 100 \\
\hline (Total) & 23 & 3 & 49 & 30.7 \\
\hline \multicolumn{5}{|c|}{ Occurrence determined in 1982} \\
\hline 1967 & 0 & 0 & 1 & 0 \\
\hline 1969 & 0 & 0 & 1 & 0 \\
\hline 1970 & 0 & 0 & 2 & 0 \\
\hline 1971 & 0 & 0 & 4 & 0 \\
\hline 1972 & 0 & 0 & 10 & 0 \\
\hline 1973 & 0 & 0 & 14 & 0 \\
\hline 1974 & 0 & 0 & 12 & 0 \\
\hline 1975 & 0 & 0 & 14 & 0 \\
\hline 1976 & 0 & 0 & 7 & 0 \\
\hline 1977 & 0 & 0 & 3 & 0 \\
\hline 1978 & 1 & 0 & 6 & 14.3 \\
\hline 1979 & 8 & 1 & 8 & 47.1 \\
\hline 1980 & 10 & 0 & 1 & 90.9 \\
\hline 1981 & 5 & 0 & 0 & 100 \\
\hline 1982 & 6 & 0 & 0 & 100 \\
\hline (Total) & 30 & 1 & 83 & 26.3 \\
\hline
\end{tabular}

type was higher during the early years of this study. The IM type appeared during the years when both the AG and NAG types were present (Table 1). A similar tendency is more clearly demonstrated for 1982, in which the 114 previously isolated strains were used (Table 1).

In comparison with the results of 1978 and 1982, almost all the strains from 1973 through 1978 ( 22 out of the 23 strains of the AG type, and 3 strains of the IM type), were determined to be either AG or IM. This is in accordance with the first determination in 1978, indicating a change to the NAG type by the second set of observation made in 1982 (cf. Table 1). This showed a shift from the AG and IM types to the NAG type in each of the strains, since the same strains which had been isolated from 1973 through 1978 were used for the second set of determination.

A strain (GKB-7301) belonging to IM type in the first determination in 1978 was used to estimate whether the IM type was a possible transitional form from AG to NAG. Agglutinative properties were examined using cell suspensions of thirty colonies isolated from this strains. In 1978, the strain was a mixture of AG and NAG types (Table 2). In 1982, however, thirty colonies isolated from the same strain were NAG (Table 2).

Virulence of $A G$ type and $N A G$ type: Virulence of seven strains was compared by $\mathrm{LD}_{50}$ determination in juvenile rainbow trout. $A n L_{50}$ of $A G$ 


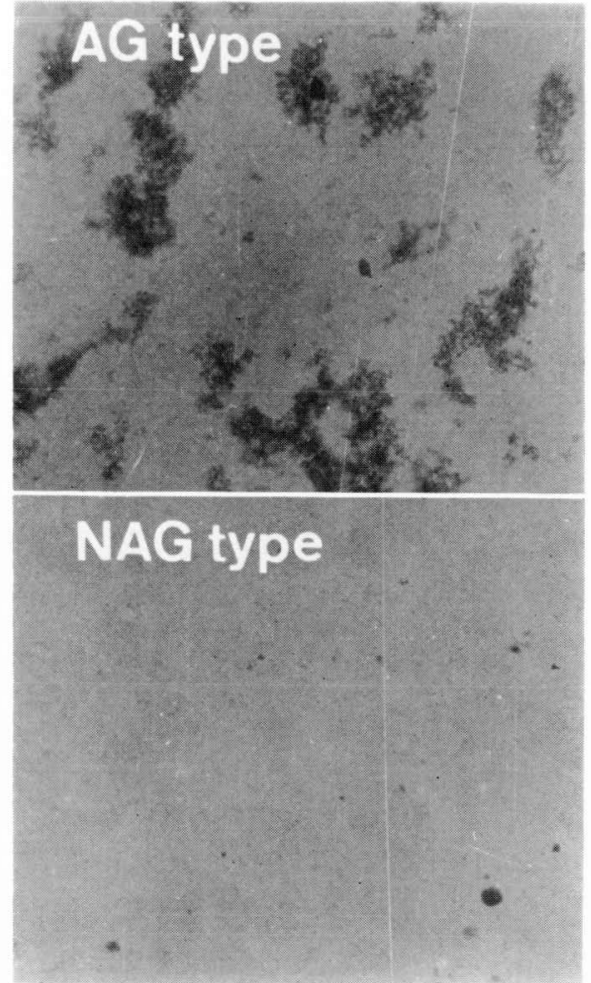

Fig. 3. Differences in flock formation for the AG and NAG types of $A$. salmonicida strains. The capacities for flock formation in the AG-type strain (A-7301) and the NAG-type strain (NCMB 1102) are observed $10 \mathrm{~min}$ after setting the cell suspensions on slide glasses under microscopy with low magnification $(\times 80)$.

type for three strains was $2.2 \times 10^{4}$ to $4.1 \times 10^{5}$ viable cells determined by ip injection, while four strains of the NAG type was more than $10^{8}$ cells (Table 3). The AG type was virulent and NAG type remained avirulent.

Yeast agglutination: Agglutination of yeast cells by $A$. salmonicida strains was determined in NAG-type cells. Agglutination was not detected in the AG-type cells (Table 3). Mannose inhibit yeast agglutination by the NAG-type cells (Table $3)$.

Susceptibility of $A G$ and $N A G$ types to serum and antibody: The susceptibility of live bacterial cells of two AG-type strains (A-7301 and E-7609-3) were maintained without serious loss (Table 4). Therefore, these strains were resistant to fresh
Table 2. Occurrence of AG-type and NAG-type colonies isolated from $A$. salmonicida strain GKB-7301 of the IM type*

\begin{tabular}{ccccc}
\hline \hline \multirow{4}{*}{$\begin{array}{c}\text { Year } \\
\text { of } \\
\text { determination }\end{array}$} & $\begin{array}{c}\text { Spontaneous } \\
\text { agglutination } \\
\text { of colonies }\end{array}$ & & AG \\
\cline { 2 - 3 } & $\begin{array}{c}\text { AG } \\
\text { type }\end{array}$ & $\begin{array}{c}\text { NAG } \\
\text { type }\end{array}$ & & AG + NAG \\
\hline 1978 & 7 & 23 & \\
1982 & 0 & 30 & & 23.3 \\
\hline
\end{tabular}

* The subculture was smeared on agar plates, and thirty colonies were selected at random. The agglutinative properties (AG/NAG) of the colonies were determined using cell suspensions prepared from the colonies. The strain was determined as IM type in 1978, but was differentiated as NAG type in 1982.

normal rainbow trout serum possessing high $\mathrm{SH}_{50}$ activity as in the treatment with heat-inactivated serum showing no $\mathrm{SH}_{50}$ activity (Table 4). However, the viable numbers of NAG-type strains (NCMB 1102 and GN-7512) drastically decreased from $10^{4}-10^{5}$ to $10-10^{2} \mathrm{~m} l^{-1}$ when treated with fresh normal serum, although heat-inactivated serum barely reduced the viability (Table 4).

In strain A-7301, the use of anti-A-7301 and anti-NCMB 1102 serums were ineffective to immune bacteriolysis. However, with complement the antiserum caused marked viability in loss with strains NCMB 1102, from approximately 10 to $10^{2-3} \mathrm{~m} l^{-1}$ (Table 5).

Responses of $A G$ and $N A G$ types to phagocytic leucocytes: Peritoneal exudate cells (PEC) collected from rainbow trout were composed of large and small leucocytes and the two types occurred in about equal numbers. The large cells were neutrophil- and macrophage-like and measured $10-20 \mu \mathrm{m}$ in diameter when stained by the WrightGiemsa method. The small cells were lymphocytes measuring 5-6 $\mu \mathrm{m}$ and possessing dense nucleus occuping almost the entire cell.

Phagocytic activity of PEC against viable bacterial cells was investigated in the presence of antiA. salmonicida (heat-inactivated) and normal rainbow trout serum using AG- and NAG-type cells as particulate antigens. This was followed by a determination of the phagocytic indices. The indices against two AG-type strains (A-7301 and E-7609-3) ranged from 0.15-0.20. Con- 
Table 3. Sources and properties of $A$. salmonicida strains, some of which are used in this study

\begin{tabular}{|c|c|c|c|c|c|c|}
\hline \multirow[b]{2}{*}{ Strain } & \multirow[b]{2}{*}{ Source } & \multirow{2}{*}{$\begin{array}{l}\text { Spontaneous } \\
\text { agglutination }\end{array}$} & \multirow{2}{*}{$\begin{array}{l}\text { Sucrose } \\
\text { marker*1 }\end{array}$} & \multicolumn{2}{|c|}{ Yeast agglutination ${ }^{* 2}$} & \multirow{2}{*}{$\begin{array}{c}\mathrm{LD}_{50} \text { dose } \\
\text { (viable } \\
\text { cells/fish) }\end{array}$} \\
\hline & & & & $\begin{array}{l}\text { Without } \\
\text { mannose }\end{array}$ & $\begin{array}{l}\text { With } \\
\text { mannose }\end{array}$ & \\
\hline A-7301 & $\begin{array}{l}\mathrm{HFH}^{* 4} \text { strain isolated from } \\
\text { sockeye salmon }\end{array}$ & AG type & $\mathrm{suc}^{+}$ & - & - & $2.2 \times 10^{4}$ \\
\hline C-7608-1 & $\begin{array}{l}\text { HFH strain isolated from } \\
\text { rainbow trout }\end{array}$ & AG type & $\operatorname{suc}^{+}$ & - & - & $4.1 \times 10^{5}$ \\
\hline E-7609-3 & $\begin{array}{l}\text { HFH strain isolated from } \\
\text { pink salmon }\end{array}$ & AG type & $\operatorname{suc}^{+}$ & - & - & $1.2 \times 10^{5}$ \\
\hline ATCC 14174 & $\begin{array}{l}\text { American Type Culture } \\
\text { Collection (USA) }\end{array}$ & NAG type & suc $^{-}$ & + & - & $>10^{8}$ \\
\hline NCMB 1102 & $\begin{array}{l}\text { National Collection of } \\
\text { Marine Bacteria (UK) }\end{array}$ & NAG type & $\mathrm{suc}^{-}$ & + & - & $>10^{8}$ \\
\hline GH-7501 & $\begin{array}{l}\text { Supplied from Inoue } \\
\text { (Daiichi Chemical Co.) }\end{array}$ & NAG type & $\mathrm{suc}^{+}$ & + & - & $>10^{8}$ \\
\hline GN-7512 & $\begin{array}{l}\text { Supplied from Inoue } \\
\text { (Daiichi Chemical Co.) }\end{array}$ & NAG type & $\operatorname{suc}^{+}$ & + & - & $>10^{8}$ \\
\hline
\end{tabular}

*1 Acid production from sucrose: suc $^{+}$, production; suc $^{-}$, no production.

$* 2 \quad+$, Positive; - , negative.

*3 By ip injections into rainbow trout.

*4 Hokkaido Fish Hatchery, Japan.

Table 4. Bactericidal action of normal rainbow trout serum against AG- and NAG-type cells of $A$. salmonicida strains

\begin{tabular}{|c|c|c|c|c|}
\hline \multirow{2}{*}{ Strain } & \multirow{2}{*}{$\begin{array}{l}\text { Treatment of cells } \\
\text { with serum }\end{array}$} & \multirow{2}{*}{$\begin{array}{l}\text { Haemolytic*1 } \\
\text { activity of } \\
\text { serum }\left(\mathrm{SH}_{50}\right)\end{array}$} & \multicolumn{2}{|c|}{$\begin{array}{l}\text { Bactericidal action*2 } \\
\text { (viable cells } / \mathrm{m} l \text { ) }\end{array}$} \\
\hline & & & Pre-treatment & Post-treatment \\
\hline \multirow[t]{3}{*}{ A-7301 (AG type) } & Physiological saline & & $5.6 \times 10^{4}$ & $6.4 \times 10^{4}$ \\
\hline & Fresh normal serum & 16.5 & $5.6 \times 10^{4}$ & $1.0 \times 10^{4}$ \\
\hline & Heat-inactivated serum*3 & $<2$ & $5.6 \times 10^{4}$ & $2.0 \times 10^{4}$ \\
\hline \multirow[t]{3}{*}{ E-7609-3 (AG type) } & Physiological saline & & $7.7 \times 10^{5}$ & $5.8 \times 10^{5}$ \\
\hline & Fresh normal serum & 18.0 & $7.7 \times 10^{5}$ & $4.3 \times 10^{5}$ \\
\hline & Heat-inactivated serum & $<2$ & $7.7 \times 10^{5}$ & $8.2 \times 10^{5}$ \\
\hline \multirow[t]{3}{*}{ NCMB 1102 (NAG type) } & Physiological saline & & $3.9 \times 10^{4}$ & $2.8 \times 10^{4}$ \\
\hline & Fresh normal serum & 16.5 & $3.9 \times 10^{4}$ & $<10$ \\
\hline & Heat-inactivated serum & $<2$ & $3.9 \times 10^{4}$ & $6.1 \times 10^{3}$ \\
\hline \multirow[t]{3}{*}{ GN-7512 (NAG type) } & Physiological saline & & $2.7 \times 10^{5}$ & $4.0 \times 10^{5}$ \\
\hline & Fresh normal serum & 18.0 & $2.7 \times 10^{5}$ & $9.4 \times 10$ \\
\hline & Heat-inactivated serum & $<2$ & $2.7 \times 10^{5}$ & $8.5 \times 10^{4}$ \\
\hline
\end{tabular}

*1 Unsensitized red blood cells of goldfish were used for $\mathrm{SH}_{50}$ assay at $30^{\circ} \mathrm{C}$ for $60 \mathrm{~min}$.

*2 Treated at $20^{\circ} \mathrm{C}$ for $2 \mathrm{~h}$; numbers of viable cells were determined by colony counts.

*3 Heated at $44^{\circ} \mathrm{C}$ for $20 \mathrm{~min}$.

siderably greater indices $(0.82-0.97)$ with NAGtype strains (NCMB 1102 and GN-7512) were observed (Table 6). This indicated that the NAG types were more susceptible to phagocytosis by leucocytes than those of the AG types. This was demonstrated by large leucocytes containing many bacterial cells in the PEC with NAG type, but scarcely with the AG type (Fig. 4).

Growth of $A G$ and $N A G$ types in mixed cultures: Differences in the in vitro growth were investigated using AG strains (A-7301 and E-7609-3, both expressing suc ${ }^{+}$) and NAG strains (NCMB 1102, 
Table 5. Immune bacteriolysis by rainbow trout antibody and complement against AG-and NAGtype cells of $A$. salmonicida strains

\begin{tabular}{|c|c|c|c|}
\hline \multirow[t]{2}{*}{ Strain } & \multirow[t]{2}{*}{ Treatment of cells with serum } & \multicolumn{2}{|c|}{$\begin{array}{l}\text { Bactericidal action*1 } \\
\quad(\text { viable cells } / \mathrm{m} l)\end{array}$} \\
\hline & & Pre-treatment & Post-treatment \\
\hline \multirow[t]{6}{*}{ A-7301 (AG type) } & Heat-inactivated anti-A-7301 serum*2 & $2.1 \times 10^{8}$ & $5.7 \times 10^{5}$ \\
\hline & Heat-inactivated anti-A-7301 serum & & \\
\hline & + fresh normal serum & $2.1 \times 10^{8}$ & $1.3 \times 10^{5}$ \\
\hline & Heat-inactivated anti-NCMB 1102 serum & $2.1 \times 10^{8}$ & $8.5 \times 10^{5}$ \\
\hline & Heat-inactivated anti-NCMB 1102 serum & & \\
\hline & + fresh normal serum & $2.1 \times 10^{8}$ & $3.3 \times 10^{5}$ \\
\hline \multirow[t]{5}{*}{ NCMB 1102 (NAG type) } & Heat-inactivated anti-A-7301 serum & $8.8 \times 10^{8}$ & $2.4 \times 10^{6}$ \\
\hline & Heat-inactivated anti-A-7301 serum & & \\
\hline & + fresh normal serum & $8.8 \times 10^{6}$ & $7.6 \times 10^{2}$ \\
\hline & Heat-inactivated anti-NCMB 1102 serum & $8.8 \times 10^{8}$ & $1.9 \times 10^{8}$ \\
\hline & $\begin{array}{l}\text { Heat-inactivated anti-NCMB } 1102 \text { serum } \\
\quad+\text { fresh normal serum }\end{array}$ & $8.8 \times 10^{6}$ & $4.0 \times 10^{2}$ \\
\hline
\end{tabular}

*1 Treated at $20^{\circ} \mathrm{C}$ for $2 \mathrm{~h}$; numbers of viable cells were determined by colony counts.

*2 Heated at $44^{\circ} \mathrm{C}$ for $20 \mathrm{~min}$.

Table 6. Phagocytic index of rainbow trout PEC against live AG- and NAG-type cells of A. salmonicida strains*1

\begin{tabular}{lcc}
\hline \multicolumn{1}{c}{ Strain } & $\begin{array}{c}\text { Number of } \\
\text { fish used } \\
\text { for PEC } \\
\text { preparation*2 }\end{array}$ & $\begin{array}{c}\text { Phagocytic } \\
\text { index } \\
\text { of PEC }\end{array}$ \\
\hline A-7301 (AG type) & 2 & 0.20 \\
E-7609-3 (AG type) & 3 & 0.15 \\
NCMB 1102 (NAG type) & 3 & 0.97 \\
GN-7512 (NAG type) & 2 & 0.82 \\
\hline$* 1$ & Live bacterial cells were exposed to PEC in the \\
& presence of the rainbow trout anti- A. salmonicida \\
serum (heat-inactivated) and complement. &
\end{tabular}

expressing suc ${ }^{-}$, and GN-7512, expressing $\mathrm{suc}^{+}$) in pure and mixed culture conditions. In the pure cultures, the viable cell counts of all strains in the nutrient broth increased equally as shown by colony counts at 2 days and 5 days. The properties of agglutination (AG/NAG) and acid production from sucrose $\left(\mathrm{suc}^{+} / \mathrm{suc}^{-}\right)$remained unchanged in the 30 isolated colonies (Table 7). However, when incubated under the mixed culture conditions, the growth of strain NCMB 1102 appeared to be more rapid than that of strain A7301. This was shown by rations of colonies exhibiting AG-suc ${ }^{+}$and $\mathrm{NAG}$-suc $^{-}$changing from

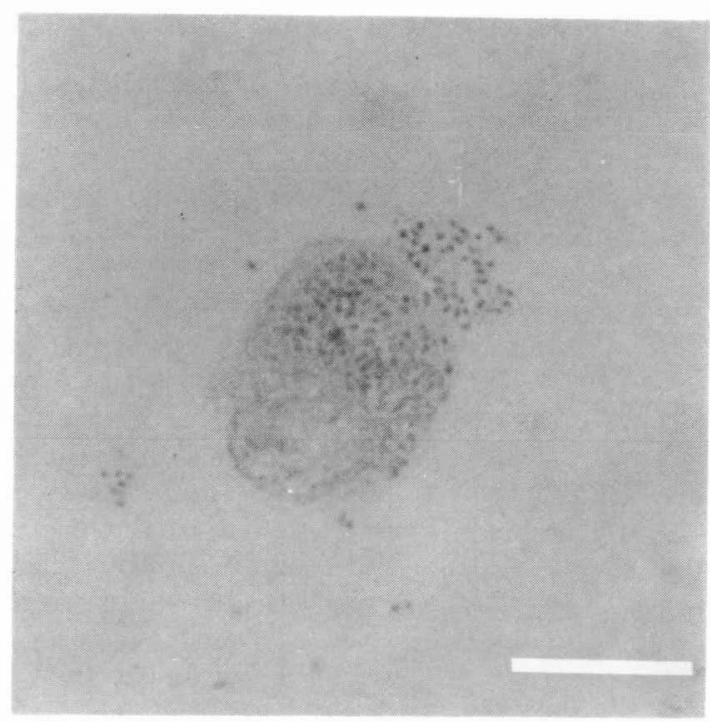

Fig. 4. Phagocytosis of NAG-type cells (strain NCMB 1102) by rainbow trout leucocytes. Bar represents $20 \mu \mathrm{m}$.

$21: 9$ in the inoculum to $13: 17$ after 2 days and then to 6:24 after 5 days (Table 7). A faster growth rate of the NAG type was also found in the mixed culture of E-7609-3 and GN-7512 (Table 7).

Growth of $A G$ and NAG types in vivo: Differences in the growth of strain A-7301 (AG-suc ${ }^{+}$) 
Table 7. Growth of AG- and NAG-type strains of $A$. salmonicida in single and mixed broth cultures*1

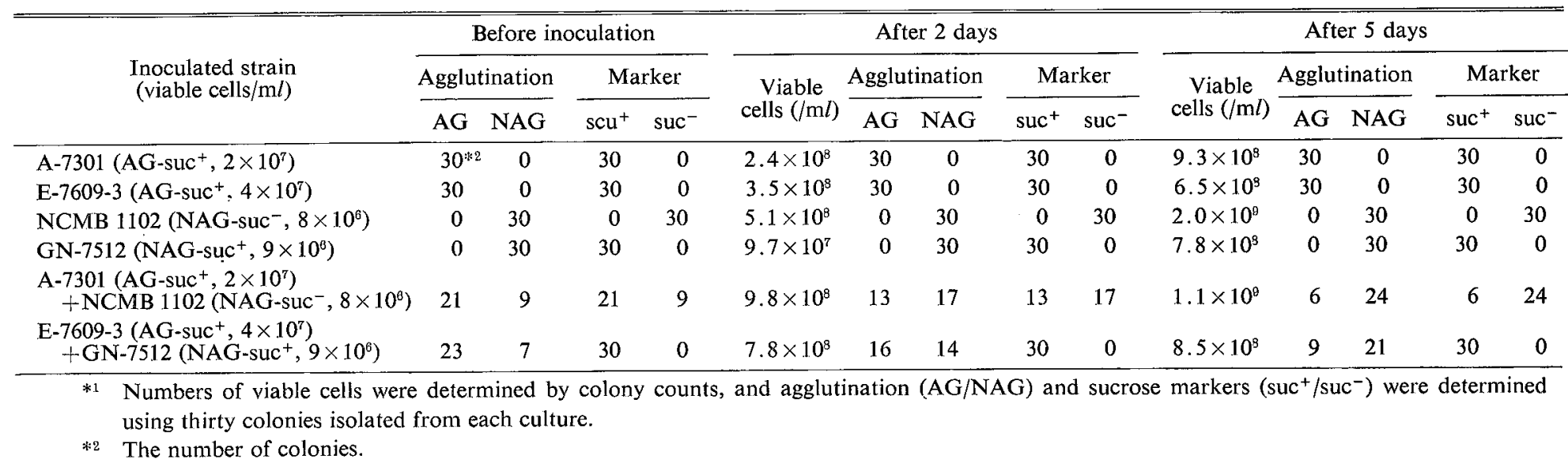

Table 8. Infectivity of AG- and NAG-type strains of $A$. salmonicida in rainbow trout in single and mixed cell injections (ip)*1

\begin{tabular}{|c|c|c|c|c|c|c|c|c|c|c|c|c|c|c|}
\hline \multirow{3}{*}{$\begin{array}{l}\text { Injected strain } \\
\text { (viable cells/fish) }\end{array}$} & \multicolumn{4}{|c|}{ Before injection } & \multicolumn{5}{|c|}{ After 2 days } & \multicolumn{5}{|c|}{ After 5 days } \\
\hline & \multicolumn{2}{|c|}{ Agglutination } & \multicolumn{2}{|c|}{ Marker } & \multirow{2}{*}{$\begin{array}{l}\text { Viable } \\
\text { cells }(/ g)\end{array}$} & \multicolumn{2}{|c|}{ Agglutination } & \multicolumn{2}{|c|}{ Marker } & \multirow{2}{*}{$\begin{array}{l}\text { Viable } \\
\text { cells }(/ g)\end{array}$} & \multicolumn{2}{|c|}{ Agglutination } & \multicolumn{2}{|c|}{ Marker } \\
\hline & AG & NAG & $\operatorname{suc}^{+}$ & $\operatorname{suc}^{-}$ & & $\mathrm{AG}$ & NAG & $\operatorname{suc}^{+}$ & $\operatorname{suc}^{-}$ & & $\mathrm{AG}$ & NAG & $\operatorname{suc}^{+}$ & suc $^{-}$ \\
\hline A-7301 (AG-suc $\left.{ }^{+}, 3 \times 10^{5}\right)$ & $30 * 2$ & 0 & 30 & 0 & $4.1 \times 10^{4}$ & 30 & 0 & 30 & 0 & $3.6 \times 10^{8}$ & 30 & 0 & 30 & 0 \\
\hline E-7603-3 (AG-suc $\left.{ }^{+}, 5 \times 10^{5}\right)$ & 30 & 0 & 30 & 0 & $5.1 \times 10^{3}$ & 30 & 0 & 30 & 0 & $1.4 \times 10^{6}$ & 30 & 0 & 30 & 0 \\
\hline NCMB $1102\left(\mathrm{NAG}-\mathrm{suc}^{-}, 6 \times 10^{5}\right)$ & 0 & 30 & 0 & 30 & $5.6 \times 10^{2}$ & 0 & 30 & 0 & 30 & $<10$ & $\mathrm{NT} * 3$ & NT & NT & NT \\
\hline GN-7512 (NAG-suc $\left.{ }^{-}, 2 \times 10^{5}\right)$ & 0 & 30 & 30 & 0 & $<10$ & NT & NT & NT & NT & $<10$ & NT & NT & NT & NT \\
\hline $\begin{array}{l}\left.\text { E-7609-3 (AG-suc }{ }^{+}, 5 \times 10^{5}\right) \\
\left.\quad+\text { GN-7512 (NAG-suc }{ }^{+}, 2 \times 10^{5}\right)\end{array}$ & 20 & 10 & 30 & 0 & $7.0 \times 10^{3}$ & 30 & 0 & 30 & 0 & $8.1 \times 10^{8}$ & 30 & 0 & 30 & 0 \\
\hline
\end{tabular}

*1 Numbers of viable cells were determined by colony counts using kidney homogenates, and agglutination (AG/NAG) and sucrose makrers (suc ${ }^{+}$! $\mathrm{suc}^{-}$) were determined using thirty colonies isolated from the homogenates.

*2 The number of colonies.

*3 Not tested. 
and/or NCMB 1102 (NAG-suc $^{-}$) and strain E7609-3 (AG-suc ${ }^{+}$) and/or GN-7512 (NAG-suc ${ }^{+}$) were investigated by ip injection into rainbow trout with viable cells. An examination of viable counts and phenotypic properties of colonies isolated from the kidneys showed the infections with AG-type strains alone resulted in progressive increases in the numbers of viable cells in the kidneys at 2 days and 5 days after injection. After 5 days, the fish became moribund and showed inflammations in the vent and haemorrhage at the base of the anal, ventral and pectoral fins, all signs of acute infection in anturally occurring furunculosis. Of the thirty colonies isolated after 2 and 5 days all were of an $\mathrm{AG}$-suc ${ }^{+}$type. In contrast, the cells of strain NCMB 1102 (NAG type) isolated from the kidneys after 2 days were lower concentration, and completely disappeared 5 days after injection (Table 8). Strain GN-7512 (NAG type) could not be isolated at 2 days. In addition, fish injected with both NAG strains showed no signs of disease. Fish receiving mixed cultures (NAG plus AG) had progressive increases in viable cell counts in the kidneys similar to infections with strain A-7301 and E-7609-3. After 5 days, the fish showed the signs of furunculosis. The ratio of AG-suc ${ }^{+}$: NAG-suc ${ }^{-}$shifted from 12: 18 (in the inoculum) to $21: 9$ after 2 days and to 30:0 after 5 days. No colony of NAG-suc ${ }^{-}$ was detected among the colonies isolated from trout receiving mixed infections of strains A-7301 and NCMB 1102. Similarly, in the mixed infection of E-7609-3 and GN-7512, only AG-suc ${ }^{+}$ type colonies were isolated after 2 and 5 days (Table 8).

\section{Discussion}

It is known that two forms exist among $A$. salmonicida strains with respect to non-immunlogical, spontaneous agglutination, an autoagglutinating form and a non-agglutinating form (EVENBERG et al., 1892; KAY et al., 1981; UDEY and FRYER, 1978). Japanese strains isolated from 1967 through 1982 were divided into AG, IM and NAG types by a turbidimetric method devised for this study (Fig. 2 and Table 1).

Based on the frequency of the three types in naturally occurring outbreaks of disease, it is apparent that a phenotypic transition develops from the AG type to the NAG type via an IM type, and that the IM is a transitional form which includes cells of both AG and NAG (Table 2). The phenotypic transition was closely related to the length of preservation after isolation; the transition $(\mathrm{AG} \rightarrow \mathrm{IM} \rightarrow \mathrm{NAG})$ commenced 3-4 years and was complete 5-6 years after isolation (cf. Table 1). This may explained in terms of the number of subcultures rather than time of preservation in nutrient agar medium. The variation may be reduced by subculture and preservation at temperature of $15^{\circ} \mathrm{C}$ or less (this study was conducted at $15^{\circ} \mathrm{C}$ ). IsHiguro et al. (1981) have reported that growth at higher than optimal :emperature results in the selection of attenuated (nonagglutinating) derivatives in the initial bacterial population of virulent (agglutinating) strains. No evidence for the occurrence of a reverse transition $(\mathrm{NAG} \rightarrow \mathrm{AG}$ or $\mathrm{NAG} \rightarrow \mathrm{IM} \rightarrow \mathrm{AG}$ ) followed by suc $^{+} /$suc $^{-}$marker was demonstrated, even when the live mixed cells consisting of AG and NAG types were cultured in vitro or injected into fish (Tables 7 and 8) (The majority of isolates in Japan, including the 114 strains used in this study are $\mathrm{suc}^{+}$; isolates from the United States, Canada and European countries, including ATCC 14174 and NCMB 1102, are generally suc ${ }^{-}$. It is not known whether $\mathrm{suc}^{+} / \mathrm{suc}^{-}$markers are associated with different pathogenic effects in fish). These findings are interpreted as shownig a lack of one or more genetic elements responsible for agglutinative properties. However, IsHiguro et al. (1981) have suggested that the variation is not due to the loss of a transfer factor or plasmid.

The literature is in agreement that agglutina.ing A. salmonicida strains are virulent to fish (EVENBERG et al., 1982; EVENBERG and LUGTENBERG, 1982; HAHNEL et al., 1983; HAMILton et al., 1982; Ishiguro et al., 1981; KAY et al., 1981; MCCARTHY and ROBERTS, 1980; UDEY and FRYER, 1978). As the $\mathrm{LD}_{50}$ shows, the results of this study also agree with the previous descriptions (Table 3 ). The IM type is probably made up of virulent and avirulent cells. IsHIGURO et al. (1981) have reported that yeast agglutination is characteristic of nonagglutinating (avirulent) strains, in which the lack of the A layer is common. According to their report, it is possible that the NAG type showing yeast agglutination (which is inhibited by mannose, as de- 
scribed by IsHiguro et al.) lacks the A layer, and that the AG type showing no yeast agglutination possesses the A layer (Table 3). In addition, strain ATCC 14174, which was used by IsHIGURo et al., showed the same results with regard to yeast agglutination, agglutinative properties and virulence.

In recent years, the bactericidal action of serum and mucus has been demonstrated in certain species of fish (Ellis, 1981; FLETCHER and GRANT, 1969; Harrell et al., 1976; INGRAM, 1980; Macvicar and Fretcher, 1970; OURTH and Wilson, 1981 and 1982a, b). SAKaI (1983a, b) demonstrated that normal rainbow trout serum possesses bactericidal action for nonagglutinating A. salmonicida and that it is proportional to the level of $\mathbf{S H}_{50}$ activity utilizing an alternative pathway for the activation of complement. The present study showed that, although the NAG strains are markedly susceptible to the serum activity, the AG strains resist it (Table 4). Furthermore, while the NAG types were more susceptible to immune bacteriolysis by a specific antibody and complement than non-specific bactericidal action by the complement alone, the AG strains largely retained their viability even in the presence of the antibody and complement (Table 5). Similar differences were found for phagocytosis by PEC in the presence of the antibody and complement. Phagocytosis by trout leucocytes and opsonization by trout antibody and complement have been reported by GRIFFIN (1983) and SAKAI (1984), implying that phagocytic cells carry Fc and $\mathrm{C}$ (complement) receptors on their cell surface. Live AG-type cells resisted phagocytosis by PEC compared to NAG-type cells (Table 6).

Serum and phagocytosis by leucocytes play essential roles in defense of the host in earlier stages of infection by microbes (AvTALION and SHAHRABANI, 1975; Ellis et al., 1976; Ellis, 1981; INGRAM, 1980; MCKINNEY et al., 1977; MCVICAR and Fletcher, 1970; MunRo, 1982; RiJkers, 1982; SyPeK and BurReson, 1983). It is evident that the viability of NAG strains is destroyed by host defense mechanisms such as bactericidal serum activity and phagocytosis (Tables 4, 5 and 6). Therefore, fish never permit the NAG type to persist within hosts (Table 8). Unlike the NAG type, the AG type is capable of avoiding the defense mechanisms by virtue of its resisting properties, thereby proliferating in and infecting fish, and causing epizootics of furunculosis.

There is a strong likelihood that the AG-type cells have cellular surface component(s) or structure(s) responsible for resistance to killing activities of the serum and to phagocytosis. MuNN et al. (1982) and TRUST et al. (1982) have claimed an important roles of the $\mathrm{A}$ layer in response to bactericidal serum activity in virulent $A$. salmonicida. On the other hand, a few virulence factors (viz. leucocytolysin, protease and haemolysin) and pretection factors against challenges have been characterized as extracellular products of virulent and avirulent strains (CIPRIANO et al., 1981; Cipriano 1982a, b; Ellis et al., 1981; Fuller et al., 1977; Karlssen, 1962; MellergaARD, 1983; MUNRo et al., 1980; MUNRO, 1982; Nomura and Saito, 1982; Shieh and McLean, 1975; Titball and MunN, 1981). The toxic factors in AG (virulent) strains would exert a severe influence on hosts as a result of bacterial propagation within the host tissues in the later stages of infection (ELLIS et al., 1981; FERGUSON and McCARTHY, 1978). NAG (avirulent) strains, however, may be eliminated from the host before the production of extracellular toxic factors (Table 8). In earlier stages, the virulence factors would be less important than the cellular surface component, because there would not yet be enough toxic products produced in the infected tissues to break down the host defenses. At present, no difference in the cell structures, with the exception of the A layer, has been discovered between the agglutinating and nonagglutinating trains. The A layer, therefore, is more likely seen as a cellular surface component.

Comparing the literature cited and the findings of this study, the following appear to be universal, even though Japanese isolates differ from those from the United States, Canada and European countries in acid production from sucrose: (a) the transition in agglutination proceeds from a positive to a negative type, (b) the reverse does not occur, (c) agglutinating types are virulent, whereas nonagglutinating types are avirulent, (d) the agglutinating type is resistant to fish serum and to phagocytosis by leucocytes but nonagglutinating type is not. 


\section{Acknowledgemnts}

The cooperation of the members of the Hokkaido Fish Hatchery, and T. Nomura, Hokkaido Salmon Hatchery, and S. Inoue, Daiichi Chemical Co., for the supply of bacterial strains, are acknowledged. We thank J. L. Fryer, Oregon State University, for improving the draft of the manuscript.

\section{References}

Atrinson, H. M. and T. J. Trust (1980): Hemagglutination properties and adherence ability of Aeromonas hydrophila. Infect. Immun. 27, 938-946.

Avtalion, R. R. and R. Shahrabani (1975): Studies on phagocytosis. I. In vitro uptake and killing of live Staphylococcus aureus by peritoneal leucocytes of carp (Cyprinus carpio). Immunol., 29, 1181-1187.

Cipriano, R. C., B. R. Griffin, and B. C. Lidgerding (1981): Aeromonas salmonicida: relationship between extracellular growth products and isolated virulence. Can. J. Fish. Aquat. Sci., 38, 1322-1326.

Cipriano, R. C. (1982a): Immunization of brook trout (Salvelinus fontinalis) against Aeromonas salmonicida: immunogenicity of virulent and avirulent isolates and protective ability of different antigens. Can. J. Fish. Aquat. Sci., 39, 218-221.

Cipriano, R. C. (1982b): Immunogenic potential of growth products extracted from cultures of Aeromonas salmonicida for brook trout (Salvelinus fontinalis). Can. J. Fish. Aquat. Sci., 39, 1512-1518.

Ellis, A. E., A. L.S. Munro, and R. J. Roberts (1976): Defence mechanisms in fish. I. A study of the phagocytic system and the fate of intraperitoneally injected particulate material in the plaice (Pleuronectes platessa L.). J. Fish. Biol., 8, 67-78.

Ellis, A. E., T.S. Hastings, and A. L. S. Munro (1981): The role of Aeromonas salmonicida extracellular products in the pathology of furnuculosis. J. Fish Dis., 4, 41-51.

Ellis, A. E. (1981): Non-specific defence mechanisms in fish and their role in disease processes, p. 337-352. In D. P. Anderson and W. Hennessen (ed.), Developments in biological standardization, vol. 49. Karger, Basel.

Eshdat, Y., I. Ofek, Y. Yashouv-Gan, N. Sharon, and D. Mirelman (1978): Isolation of mannosespecific lectin from Escherichia coli by the ionic detergent sodium lauryl sarcosinate. J. Bacteriol., 115, 717-722.

Evenberg, D., R. V. Boxtel, B. Lugtenberg, F. SCHURer, J. Blommaert, and R. Bootsma (1982):
Cell surface of the fish pathogenic bacterium Aeromonas salmonicida. I. Relationship between autoagglutination and the presence of a major cell envelope protein. Biochim. Biophys. Acta, 684, 214-248.

EvenberG, D. and B. Lugtenberg (1982): Cell surface of the fish pathogenic bacterium Aeromonas salmonicida. II. Purification and characterization of a major cell envelope protein related to autoagglutination, adhesion and virulence. Biochim. Biophys. Acta, 684, 249-254.

Ferguson, H.W., and D. H. MCCarthy (1978): Histopathology of furnuculosis in brown trout Salmo trutta L. J. Fish Dis., 1, 165-174.

Fletcher, T. C. and P. T. Grant (1969): Immunoglobulins in the serum and mucus of the plaice (Pleuronectes platessa). Biochem. J., 115, $65 \mathrm{p}$.

Fuller, D. W., K. S. Pilcher, and J. L. Fryer (1977): A leukocytolytic factor isolated from cultures of Aeromonas salmonicida. J. Fish. Res. Board Can., 34, 1118-1125.

GrIfFIN, B. R. (1983): Opsonic effect of rainbow trout (Salmo gairdneri) antibody on phagocytosis of Yersinia ruckeri by trout leukocytes, Dev. Comp. Immunol., 7, 253-259.

Hahnel, G. B., R. W. Gould, and E. S. Boatman (1983): Serological comparison of selected isolates of Aeromonas salmonicida ssp. salmonicida. J. Fish Dis., 6, 1-11.

Hamilton, R. C., H. Kainis, N. R. Acklan, and L. D. Ashburner (1981): An extra layer in the surface layers of an atypical Aeromonas salmonicida isolated from Australian goldfish. J. gen. Microbiol., 122, 363-366.

Harrell, L. W., H. H. EtLINGer, and H. O. Hodgins (1976): Humoral factors important in resistance of salmonid fish to bacterial diseases. III. AntiVibrio anguillarum activity in mucus and observations on complement. Aquaculture, 7, 373-370.

Herman, R. L. (1968): Fish furunculosis, 1952-1966. Trans. Am. Fish. Soc., 97, 221-230.

INGRAM, G. A. (1980). Substances involved in the natural resistance of fish to infection-a review. $J$. Fish. Biol., 16, 23-60.

Ishiguro, E. E., W. W. Kay, T. Ainsworth, J. B. Chamberlain, R. A. Austin, J. T. Buckley, and T. J. TRust (1981): Loss of virulence during culture of Aeromonas salmonicida at high temperature. $J$. Bacteriol., 148, 333-340.

KARLSSEN, K. A. (1962): Studies of the haemolysin of Aeromonas salmonicida. Nord. Veterinaermed., 14 (Suppl. 2).

Kay, W. W., J. T. Buckley, E E. Ishiguro, B. M. Phipps, J. P. L. Monette, and T. J. Trust (1981): Purification and disposition of a surface protein 
associated with virulence of Aeromonas salmonicida. J. Bacteriol., 147, 1077-1084.

Klontz, G. W., W. T. Yasutake, and A. J. Ross (1966): Bacterial diseases in the salmonidae in the western United States: pathogenesis of furnuculosis in rainbow trout. Am. J. Vet. Res., 27, 1455-1460.

MCCARThy, D. H. and R. J. Roberts (1980): Furunculosis of fish - the present state of our knowledge, p. 293-341. In M. R. Droop and H. W. Jannasch (ed.), Advances in aquatic microbiology, vol. 2. Academic Press, London.

McKinney, E. C., S. B. Smith, H. G. Haines, and M. M. Sigel (1977): Phagocytosis by fish cells. J. Reticuloendothel. Soc., 21, 89-95.

McVicar, A. H. and T. C. Fletcher (1970): Serum factors in Raja radiata toxic to Acanthobothrium quadripartitum (Cestoda: Tetraphyllidaea), a parasite specific to $R$. naevus. Parasitology, 61, 55-63.

MellergaArd, S. (1983): Purification and characterization of new proteolytic enzyme produced by Aeromonas salmonicida. J. appl. Bacteriol., 54, 289294.

MunN, C. B., E. E. Ishiguro, W. W. KaY, and T. J. Trust (1982): Role of surface components in serum resistance of virulent Aeromonas salmonicida. Infect. Immun., 36, 1069-1075.

Munro, A. L. S., T. S. Hastings, A. E. Ellis, and J. LIVERSIDGE (1980): Studies on an ichthyotoxic material produced extracellularly by the furunculosis bacterium, Aeromonas salmonicda, p. 98-106. In W. Ahne (ed.), Fish diseases: Third COPRAQSession. Springer Verlag, Berlin.

MunRo, A. L. S. (1982): The pathogenesis of bacterial diseases of fishes, p. 131-149. In R. J. Roberts (ed.), Microbial diseases of fish. Academic Press, London.

Nomura, S. and H. SaIto (1982): Production of the extracellular hemolytic toxin by an isolated strain of Aeromonas salmonicida. Bull. Japan. Soc. Sci. Fish., 48, 1589-1597.

Ourth, D. D. and E. A. Wilson (1981): Agglutination and bactericidal responses of the channel catfish to Salmonella paratyphi. Dev. Comp. Immunol., 5, 261-269.

Ourth, D. D. and E. A. Wilson (1982a): Alternate pathway of complement and bactericidal response to the channel catfish to Salmonella paratyphi. Dev. Comp. Immunol., 6, 75-85.

Ourth, D. D. and E. A. Wilson (1982b): Bactericidal serum response of the channel catfish against gramnegative bacteria. Dev. Comp. Immunol., 6, 570583.

RIJKers, G. T. (1982): Non-lymphoid defense mechanisms in fish. Dev. Comp. Immunol., 6, 1-13.

SAKAI, D. K. (1981a): Heat inactivation of complements and immune hemolysis reactions in rainbow trout, masu salmon, coho salmon, goldfish and tilapia. Bull. Japan. Soc. Sci. Fish., 47, 565-571.

SAKAI, D. K. (1981b): Spontaneous and antibodydependent hemolysis activities of fish sera and inapplicability of mammalian complements to the immune hemolysis reaction of fishes. Bull. Japan. Soc. Sci. Fish., 47, 979-991.

SAKAI, D. K. (1981c): Separation of lymphocytes from the peripheral blood of rainbow trout and goldfish. Bull. Japan. Soc. Sci. Fish., 47, 12811288.

SAKAI, D. K. (1983a): Lytic and bactericidal properties of salmonid sera. J. Fish Biol., 23, 457-466.

SAKAI, D. K. (1983b): The activation of alternative pathway by pronase, LPS and zymosan in the complement system of rainbow trout serum. Bull. Japan. Soc. Sci. Fish., 49, 347-351.

SAKAI, D. K. (1984): Opsonization by fish antibody and complement in the immune phagocytosis by peritoneal exudate cells isolated from salmonid fishes. J. Fish. Dis., 7, 29-38.

ShieH, H. S. and J. R. McLean (1975): Purification of properties of an extracellular protease of Aeromonas salmonicida, the causative agent of furunculosis. Int. J. Biochem., 6, 653-656.

SyPeK, J. P. and E. M. BurReson (1983): Influence of temperature on the immune response of juvenile summer flounder, Paralichthys dentatus, and its role in the elimination of Trypanoplasma bullocki infections. Dev. Comp. Immunol., 7, 277-286.

Titball, R. W. and C. B. MunN (1981): Evidence for two haemolytic activities from Aeromonas salmonicida. FEMS Microbiol. Letters, 12, 27-30.

Trust, T. J., W. W. Kay, E. E. Ishiguro, J. T. Buckley, and T. W. Pearson (1982): Properties of A protein, a virulence factor on the surface of Aeromonas salmonicida. Dev. Comp. Immunol., 6 (Suppl. 1).

Uedy, L. R. and J. L. Fryer (1978): Immunization of fish with bacterins of Aeromonas salmonicida. Mar. Fish. Rev., 40, 12-17. 